\title{
PENDEKATAN INTERDISIPLINER TERHADAP PERILAKU KONSUMEN BANK SYARI'AH
}

\author{
Oleh: Syaifuddin, SE, MEI ${ }^{1}$
}

\begin{abstract}
Interdisciplinary is a collaboration between several disciplines to respond to developments and problems of buman civilization. Mu'amalah science, economics, sociology, and psychology work together to examine the behavior of Muslim consumers. Consumer behavior is the study of how individuals, groups and organizations select, purchase, use and dispose of goods, services, ideas or experiences to satisfy their wants and needs. Consumer bebavior studies focused on how individuals make the decision to utilize their resources (time, money and effort) to buy goods and services consumed. This interdisciplinary approach to the Islamic bank consumer behavior is required, because basically Islamic economics as a subject of study is the contribution of the various sciences. In a study of consumer behavior resulted in two conclusions Islamic bank. Religiosity influences customer behavior Islamic bank, and other conclusions stated that in a certain level of religiosity does not affect the behavior of bank customers Shari'ah.
\end{abstract}

Keywords: Approach, Interdisciplinary, Behavior, Consumer, Bank, Shari ah.

\section{A. Pendahuluan}

Perkembangan ilmu pengetahuan dewasa ini semakin kompleks dan tidak terbatas pada induk, cabang serta ranting ilmu pengetahuan. Berbagai problema dan perkembangan peradaban manusia menuntut suatu pengembangan ilmu tertentu agar kehidupn manusia menjadi semakin beradab.

Pada awal perkembangan ilmu pengetahuan memiliki ciri-ciri monodisipliner, artinya suatu disiplin ilmu tentu dengan menggunakan metode tertentu disamping ilmu-ilmu lainnya, baik ilmu teoritis maupun ilmu praktis. Pada abad modern ilmu pengetahuan berkembang semakin pesat dan ditandai dengan semakin berkembangnya pula spesialisasi pada disiplin masing-masing, sehingga berkembanglah apa yang disebut dengan multidisipliner. Untuk memenuhi kebutuhan praktis antar ilmu pengetahuan saling menggabungkan diri dengan suatu

1 Dosen tetap IAIN Ternate. Kandidat Doktor Ekonomi Syariah di UIN Sunan Ampel Surabaya. Alamat Dufa-dufa Pantai Kota Ternate, Propinsi Maluku Utara. Email : ifudsby@yahoo.co.id 
metode baru. Hubungan dan kerjasama ilmu yang demikian ini disebut sebagai ilmu yang interdisipliner. Ilmu-ilmu interdisipliner ini telah merupakan suatu disiplin ilmu tersendiri dengan seperangkat metodenya sendiri. ${ }^{2}$

Ekonomi Islam sebagai disiplin ilmu, menumbuhkan harapan besar sekaligus tantangan yang kompleks. Sebagai ekonomi alternatif ${ }^{3}$, ilmu ekonomi Islam harus membuka diri terhadap ilmu-ilmu sosial agar dapat memecahkan masalah-masalah ekonomi untuk mencapai tujuan ekonomi Islam yang selaras dengan Maqas $\}$ id alShari $a b^{4}$. Ekonomi Islam dalam perkembangannya telah menunjukkan daya tarik yang sama besar antara kebutuhan ilmu agama dan sekuler untuk memperkaya kajiannya. Ekonomi Islam memerlukan kajian hukum Islam, fiqh mu'amalah, tafsir, Ushl al Fiqh dan tarikh dan disiplin ilmu keagamaan lainnya. Di sisi lain ekonomi Islam juga membutuhkan statistik, ekonometri, sosiologi, psikologi, antropologi, sejarah, dan ekonomi konvensional untuk memecahkan masalah-masalah ekonomi dalam kajiannya. Karenanya kajian ekonomi Islam merupakan intergrasi pengetahuan dari teori ekonomi, fiqh mu'amalah yang ditunjang oleh sosiologi, antropologi budaya dan ilmu perilaku. ${ }^{5}$

Ekonomi Islam merupakan usaha untuk memahami masalah ekonomi dan perilaku manusia serta hubungan keduanya dalam perspektif Islam ${ }^{6}$. Fokus kajian ekonomi Islam selain doktrin dan sains, juga perilaku' ${ }^{7}$ Untuk memahami perilaku ekonomi diperlukan konsep keterlekatan, yaitu tindakan ekonomi yang disituasikan secara sosial dan melekat dalam jaringan sosial personal yang sedang berlangsung diantara para aktor. Aktifitas ekonomi tidak hanya semata-mata dilandasi oleh motif

\footnotetext{
${ }^{2}$ Kaelan, Metode Penelitian Agama Kualitatif Interdisipliner (Yogyakarta: Paradigma, 2010), 34.

${ }^{3}$ M. Umer Chapra, Islam and the Economics Challenge (Leicester, UK : The Islamic Foundation, 1992), 201-212.

${ }^{4}$ Maqas $\}$ id al-Shari 'ah atau tujuan shari'ah yang lima (perlindungan terhadap agama, jiwa, akal, keturunan, dan harta).

${ }^{5}$ Ismail Nawawi Uha, Isu-Isu Ekonomi Islam : Kompilasi Pemikiran dan Teori Menuju Praktik di Tengah Arus Ekonomi Global. Buku 1 Nalar Filsafat (Jakarta: Viv Press, 2013), 45.

${ }^{6}$ Chapra, Islam and the Economics Challenge, 23.

${ }^{7}$ Uha, Buku 1 Nalar Filsafat, 47-48.
} 
keuntungan, tetapi terdapat faktor agama, budaya dan struktur sosial yang mempengaruhi aktor. ${ }^{8}$

Aktifitas ekonomi selalu terkait dengan kegiatan produksi, distribusi dan konsumsi. Untuk memahami bagaimana upaya individu memenuhi kebutuhannya dengan sumberdaya yang dimilikinya maka dilakukan studi perilaku konsumen. Sangatlah penting untuk mempelajari bagaimana konsumen berperilaku dan faktorfaktor apa saja yang mempengaruhi perilaku tersebut. Perilaku konsumen adalah studi bagaimana individu, kelompok dan organisasi memilih, membeli, menggunakan dan menempatkan barang, jasa, ide atau pengalaman untuk memuaskan keinginan dan kebutuhan mereka. ${ }^{9}$

Beberapa ahli ekonomi syariah telah membuat kesimpulan menarik berkaitan dengan hubungan antara perilaku ekonomi (economic behavior) dan tingkat keyakinan masyarakat. ${ }^{10}$ Perilaku ekonomi sangat ditentukan oleh tingkat keimanan seseorang atau masyarakat. Perilaku ini kemudian membentuk kecenderungan perilaku konsumsi dan produksi di pasar. Perspektif tersebut juga berpengaruh terhadap perilaku konsumen bank syari'ah. Menurut Mooduto, kemantapan dan keteguhan, serta keyakinan seseorang terhadap kehalalan operasionalisasi perbankan syariah dalam segala produk dan aspek hukumnya merupakan cermin religiusitas. ${ }^{11}$

Terdapat berbagai penelitian yang telah dilakukan sebagai upaya menguji dan sekaligus mengembangkan teori di atas. Penelitian tentang pengaruh agama terhadap perilaku nasabah bank syari'ah dilakukan oleh peneliti di luar Indonesia antara lain oleh : Erol dan El-Bdour (1989) ${ }^{12}$, Haron et al. (1994), Gerrard dan Cunningham,

${ }^{8}$ M. Granovetter, "Problem of Explanation in Economic Sociology", dalam Network and organizations: Structure from and Action, ed. N. Nohria et al. (Boston: Harvard Businnes School Press, 1992), 382.

${ }_{9}^{9}$ Philip Kotler dan Keller, Kevin Lane, Manajemen pemasaran Edisi 12 jilid 2. Ter. Benyamin Molan (Jakarta: Indeks, 2008), 214.

${ }^{10}$ H.S.H. Omer, "The implications of Islamic beliefs and practice on the Islamic financial institutions in the UK: case study of Albaraka International Bank UK"(Desertasi --Loughborough University, Loughborough ,1992), 112.

${ }^{11}$ Mehboob ul Hassan, "People's Perceptions towards the Islamic Banking: A Fieldwork Study on Bank Account Holders' Behaviour in Pakistan" (Desertasi-- School of Economics, Nagoya City University Japan, 2007), 467-850.

${ }^{12}$ Erol, C and El-Bdour R. "Attitudes, Behaviour and Patronage Factors of Bank Customers Towards" International Journal of Bank Marketing 4 (1989), 15. 
Jalaluddin dan Metwally (1999). ${ }^{13}$ Sedang peneliti Indonesia antara lain : Anny Ratnawati, et. al. (2000), Jazim Hamidi, et. al. (2000). ${ }^{14}$

Jika berbagai hasil penelitian di atas melihat agama bukanlah merupakan motivasi utama dalam memanfaatkan perbankan syariah, maka penelitian-penelitian di bawah ini justeru berbalikan. Agama merupakan faktor penting ditunjukkan oleh peneliti di luar Indonesia seperti: Omer (1992), Hegazy (1995), Metwally (1996), Metawa dan Almossawi (1998), ${ }^{15}$ al-Sultan (1999) ${ }^{16}$, Ahmad dan Haron (2002), Okumus (2005), Kadom dan Alzafiri (2008), ${ }^{17}$ Mehboob ul Hassan (2007). Sedang penelitian dalam negeri dilakukan oleh : Nur Widiastuti (2003) ${ }^{18}$.Fatmah $(2005){ }^{19}$ dan Muhlis. ${ }^{20}$

Dua kategori penelitian tersebut di atas mengelaborasi perilaku konsumen dari faktor internal konsumen (afeksi dan kognisi) serta faktor eksternal (rangsangan pemasaran). Paradigma positivistik dalam penelitian perilaku konsumen paralel dengan kecenderungan studi ekonomi. Akibatnya tercipta gap penelitian, sehingga eksplorasi lingkungan sosial dalam pembentukan perilaku konsumen bank syari'ah sangat kurang.

\section{B. Pembahasan}

${ }^{13}$ M. Metwally, "The Impact of Demographic Factors on Consumers' Selection of a Particular Bank within a Dual Banking System: A Case Study." Journal of International Marketing and Marketing Research 27(2002): 35-44.

${ }^{14}$ Jazim Hamidi, et al., "Persepsi dan Sikap Masyarakat Santri Jawa Timur terhadap Bank Syariah", (Malang: BI dan Universitas Brawijaya Malang, 2000), 45.

${ }^{15} \mathrm{~S}$. Metawa, and M. Almossawi, "Banking Behaviour of Islamic Bank Customers: Perspectives and Implications." International Journal of Bank Marketing 16(7) (1998): 299-315.

${ }^{16}$ W. al-Sultan, "Financial Characteristics of Interest-Free Banks and Conventional Bank Accounting and finance”(Desertasi-- The University of Wollongong, Wollongong, 1999), 221-234.

${ }^{17} \mathrm{~N}$. Ahmad and S. Haron, "Perceptions of Malaysian Corporate Customers Towards Islamic Banking Products and Services." International Journal of Islamic Financial Services Vol. 3 (2002). , 1 16.

${ }^{18}$ Nur Widiastuti, "Pengaruh Relijiusitas, Pendapatan, dan Tanggungan Keluarga terhadap Jumlah Tabungan”, Jurnal Telaab Bisnis, Vol.4, Nomor 2(Desember 2003), 27

${ }^{19}$ Fatmah, "Pengaruh Persepsi Religiusitas, Kualitas Layanan, dan Inovasi Produk terhadap Kepercayaan dan Komitmen serta Loyalitas Nasabah Bank Umum Syariah di Jawa Timur” (Desertasi- Unair Surabaya Surabaya, 2005).

${ }^{20}$ Muhlis, "Perilaku Menabung di Perbankan Syari'ah Jawa Tengah" (Desertasi-Universitas Diponegoro, Semarang, 2011), 238-241. 
Perilaku konsumen adalah studi bagaimana individu, kelompok dan organisasi memilih, membeli, menggunakan dan menempatkan barang, jasa, ide atau pengalaman untuk memuaskan keinginan dan kebutuhan mereka. ${ }^{21}$ Studi perilaku konsumen terpusat pada cara individu mengambil keputusan untuk memanfaatkan sumberdaya yang mereka miliki (waktu, uang dan usaha) guna membeli barang dan jasa yang dikonsumsi. ${ }^{22}$

Elemen utama dalam kerangka kerja konseptual perilaku konsumen ada empat, yaitu (1) efeksi (affect) dan kognisi (cognition), (2) perilaku (behavior), (3) lingkungan, dan (4) strategi pemasaran (marketing strategy). Elemen efeksi dan kognisi merupakan dua tipe tanggapan internal psikologis pada diri konsumen terhadap rangsangan lingkungan dan kejadian yang berlangsung. Afeksi melibatkan perasaan, sedangkan kognisi melibatkan pikiran. ${ }^{23}$

Kognisi merupakan proses mental dan psikologis serta struktur pengetahuan yang dilibatkan dalam tanggapan seseorang terhadap lingkungannya. Hal tersebut termasuk pengetahuan yang didapat dari pengalaman dan pengetahuan yang telah tertanam dalam memori. Proses psikologi yang termasuk dalam aspek kognisi diantaranya perhatian dan pemahaman terhadap aspek lingkungan, mengingat kejadian masa lalu, pembentukan evaluasi, dan pembuatan keputusan pembelian. Aspek kognisi bisa terjadi melalui proses berpikir sadar ataupun dapat terjadi secara tidak sadar dan otomatis.

Perilaku (behavior) adalah tindakan nyata konsumen yang dapat diobservasi secara langsung. Afeksi dan kognisi mengacu pada perasaan dan pikiran konsumen, sedangkan perilaku berhubungan dengan apa yang sebenarnya dilakukan oleh konsumen.

Sedangkan yang dimaksud elemen lingkungan (environment) adalah menujuk pada rangsangan fisik dan sosial yang komplek di luar diri (eksternal) konsumen. Diantaranya adalah benda-benda, tempat dan orang lain yang dapat mempengaruhi

${ }^{21}$ Philip Kotler dan Keller, Kevin Lane, Manajemen pemasaran Edisi 12 jilid 2. Ter. Benyamin Molan (Jakarta: Indeks), 214.

${ }^{22}$ Leon G. Schiffman dan Leslie Lazar Kanuk, Perilaku Konsumen terj. Zoelkifli Kasip, (Jakarta:Indeks, 2008), 6.

${ }^{23}$ Rini Dwi Astuti et. al, Ilmu Perilaku Konsumen (Malang : UB Press, 2012), 25-27. 
efeksi, kognisi serta perilaku konsumen. Adapun yang dimaksud dengan elemen strategi pemasaran dalam kerangka kerja konseptual adalah penempatan rangsangan pemasaran dalam lingkungan. Beberapa rangsangan tersebut adalah produk dan jasa, materi promosi (iklan), tempat penjualan (toko eceran), informasi tentang harga yang ditempel pada produk.

Perilaku konsumen dapat dibentuk dan diubah. Perilaku dimulai dari pembentukan sikap, yaitu kecenderungan yang dipelajari dalam berperilaku dengan cara menyenangkan atau tidak menyenangkan terhadap suatu objek. Sikap mempunyai 3 komponen yaitu kognitif (pengetahuan dan persepsi konsumen), afektif (emosi atau perasaan konsumen) dan konatif (kecenderungan konsumen). Strategi mengubah sikap konsumen dapat dilakukan dengan pendekatan fungsional. Perilaku dapat mendahului atau mengikuti pembentukan sikap. ${ }^{24}$

Selain faktor internal pembentuk perilaku konsumen adalah lingkungan sosial. Pembentukan perilaku juga dapat dipengaruhi oleh keluarga dan kelompok rujukan. Kelompok rujukan merupakan setiap orang atau kelompok yang dijadikan dasar perbandingan bagi seseorang untuk membentuk nilai dan sikap. ${ }^{25} \mathrm{Nahz}$ \} iyin dengan figur kyai dan komunitas mempunyai pengaruh signifikan dalam membentuk perilaku ekonomi umat.

Sosiologi ekonomi diperlukan untuk memahami konsumen dalam lingkungan sosialnya. Untuk memahami perilaku individu dalam kelompok maka digunakan teori struktural fungsional (makro) dan interaksionisme simbolik (mikro). ${ }^{26}$ Teori struktural fungsional menjelaskan bahwa setiap struktur akan tetap ada sepanjang ia memiliki fungsi ${ }^{27}$. Asumsi teori ini menyatakan setiap masyarakat terdiri atas berbagai elemen yang terstruktur secara relatif mantap dan stabil, yang terintegrasi dengan baik serta dilandaskan konsensus nilai antar para anggota. Teori interaksionisme simbolik memahami realitas sebagai suatu interaksi yang dipenuhi berbagai simbol, individu secara aktif mengkonstruksikan tindakan-tindakannya dan individu menyesuaikan diri

\footnotetext{
${ }^{24}$ Leon G. Schiffman dan Leslie Lazar Kanuk, Perilaku Konsumen ter. Zoelkifli Kasip, (Jakarta:Indeks, 2008), 321-358.

25 Ibid., 291-300

${ }^{26}$ Damsar dan Indrayani, Pengantar Sosiologi Ekonomi, (Jakarta: Kencana, 2013), 49-51.

${ }^{27}$ George Ritzer \& Douglas J. Goodman Teori Sosiologi Modern, terj. Imam Muttaqien (Jakarta: Pranada Media, 2005), 273.
} 
dalam proses interaksi ${ }^{28}$ Penggunaan teori struktural fungsional dan interaksionis simbolik secara bersamaan berguna untuk memahami perilaku individu dalam kelompok.

Perilaku konsumen muslim dipengaruhi oleh keberagamaan. Dalam perkembangannya, agama tidak bisa lagi dipahami secara orthodok, yakni hanya semata-mata terkait dengan persoalan ketuhanan atau keimanan semata. ${ }^{29}$ Keberagamaan (religiusitas) diwujudkan dalam berbagai aspek kehidupan manusia. Gejala ini disebut sebagai internalisasi nilai-nilai ajaran agama yang diyakini tidak mustahil dan tidak bertentangan dengan logika yang kemudian diekspresikan dalam kehidupan sosial kemasyarakatan. Kaitannya dengan wujud perilaku keagamaan maka religiusitas dianalisis ke dalam lima dimensi, yaitu dimensi keyakinan, praktik, pengalaman, pengetahuan, dan konsekuensi: ${ }^{30}$

Studi perilaku konsumen terpusat pada cara individu mengambil keputusan untuk memanfaatkan sumberdaya yang mereka miliki (waktu, uang dan usaha) guna membeli barang dan jasa yang dikonsumsi. ${ }^{31}$ Perilaku konsumen adalah studi bagaimana individu, kelompok dan organisasi memilih, membeli, menggunakan dan menempatkan barang, jasa, ide atau pengalaman untuk memuaskan keinginan dan kebutuhan mereka. ${ }^{32}$

Studi perilaku konsumen berakar pada strategi pemasaran yang berkembang pada akhir 1950-an, kemudian mapan menjadi studi tersendiri pada ahir 1960-an. Karena ilmu ini tidak mempunyai sejarah atau badan risetnya sendiri sehingga para pengembangnya meminjam berbagai konsep yang dikembangkan berbagai disiplin ilmu pengetahuan lain, seperti psikologi (studi mengenai individu), sosiologi (studi mengenai kelompok), psikologi sosial (studi mengenai cara individu beroperasi dalam kelompok), antropologi (pengaruh masyarakat pada individu) dan ilmu ekonomi. ${ }^{33}$

\footnotetext{
28 P.J. Johnson, Teori Sosiologi Klasik dan Modern Jilid 1 (Jakarta: Gramedia, 1981), 37.

${ }^{29}$ Amin Abdullah, Dinamika Islam Kultural.(Bandung : Mizan, 2000), 126.

30 C.Y. Glock, and R. Stark, American Piety : The Nature of Religious Commitment, (USA: University of Chicago Press, 1968), 328.

31 Leon G. Schiffman dan Leslie Lazar Kanuk, Perilaku Konsumen terj. Zoelkifli Kasip, (Jakarta:Indeks, 2008), 6.

32 Philip Kotler dan Keller, Kevin Lane, Manajemen pemasaran Edisi 12 jülid 2. Ter. Benyamin Molan (Jakarta: Indeks), 214.

${ }^{33}$ Leon G. Schiffman dan Leslie Lazar Kanuk, Perilaku Konsumen, 7.
} 
Perilaku konsumen sangat dipengaruhi oleh keadaan dan situasi lapisan masyarakat dimana ia dilahirkan dan berkembang. Ini berarti konsumen berasal dari lapisan masyarakat atau lingkungan yang berbeda akan mempunyai penilaian, kebutuhan, pendapat, sikap, dan selera yang berbeda-beda, sehingga pengambilan keputusan dalam tahap pembelian akan dipengaruhi oleh beberapa faktor. Faktor yang mempengaruhi perilaku konsumen terdiri dari: faktor kebudayaan, faktor sosial, faktor pribadi dan faktor psikologis. ${ }^{34}$

Pengambilan keputusan konsumen berbeda-beda tergantung pada jenis keputusan pembelian. Assael membedakan empat jenis perilaku pembelian konsumen berdasarkan tingkat keterlibatan pembeli dan tingkat perbedaan merek-merek. Berikut merupakan gambar jenis pengambilan keputusan beli: ${ }^{35}$

\begin{tabular}{|l|l|l|}
\hline & \multicolumn{1}{|c|}{$\begin{array}{c}\text { KETERLIBATAN } \\
\text { TINGGI }\end{array}$} & \multicolumn{1}{|c|}{$\begin{array}{c}\text { KETERLIBATAN } \\
\text { RENDAH }\end{array}$} \\
\hline $\begin{array}{l}\text { Pengambilan } \\
\text { Keputusan }\end{array}$ & $\begin{array}{l}\text { Keputusan Pembelian Yang Rumit } \\
\text { Kebiasaan }\end{array}$ & $\begin{array}{l}\text { Perilaku Pembelian Yang } \\
\text { Mencari Variasi }\end{array}$ \\
& $\begin{array}{l}\text { Perilaku Pembelian Pengurang } \\
\text { Ketidaknyamanan }\end{array}$ & $\begin{array}{l}\text { Perilaku Pembelian } \\
\text { Karena Kebiasaan }\end{array}$ \\
\hline
\end{tabular}

Salah satu pendekatan utama dalam meneliti perilaku konsumen adalah pendekatan interpretif. Pendekatan ini menggali secara mendalam perilaku konsumsi dan hal yang mendasarinya. Studi dilakukan dengan melalui wawancara panjang dan focus group discussion untuk memahami apa makna sebuah produk dan jasa bagi konsumen dan apa yang dirasakan dan dialami konsumen ketika membeli dan menggunakannya. ${ }^{36}$

Untuk memahami bagaimana pembentukan perilaku konsumen, maka para ahli menawarkan model perilaku konsumen. Model perilaku konsumen menggambarkan bagaimana terbentuknya perilaku konsumen secara holistik. Model

${ }^{34}$ Philip Kotler dan Keller, Kevin Lane, Manajemen pemasaran, 25.

${ }^{35} \mathrm{H}$ Assael. Consumer Behavior and marketing Action. ( Boston: Wadsworth ,1992), 25.

${ }^{36}$ Ismail Nawawi Uha, Ekonomi Manajerial: teori dan Aplikasi Dalam Bisnis (Sidoarjo, Dwiputra Pustaka Jaya, 2014), 163-165. 
perilaku konsumen dapat diartikan sebagai kerangka kerja atau alur yang mewakili apa yang diinginkan konsumen dalam mengambil keputusan membeli. Atau model perilaku konsumen dapat didefinisikan sebagai skema yang disederhanakan untuk menggambarkan aktivitas-aktivitas konsumen. $^{37}$ Kotler menggambarkan model perilaku konsumen sebagai berikut: ${ }^{38}$

Model Perilaku Konsumen Philip Kotler

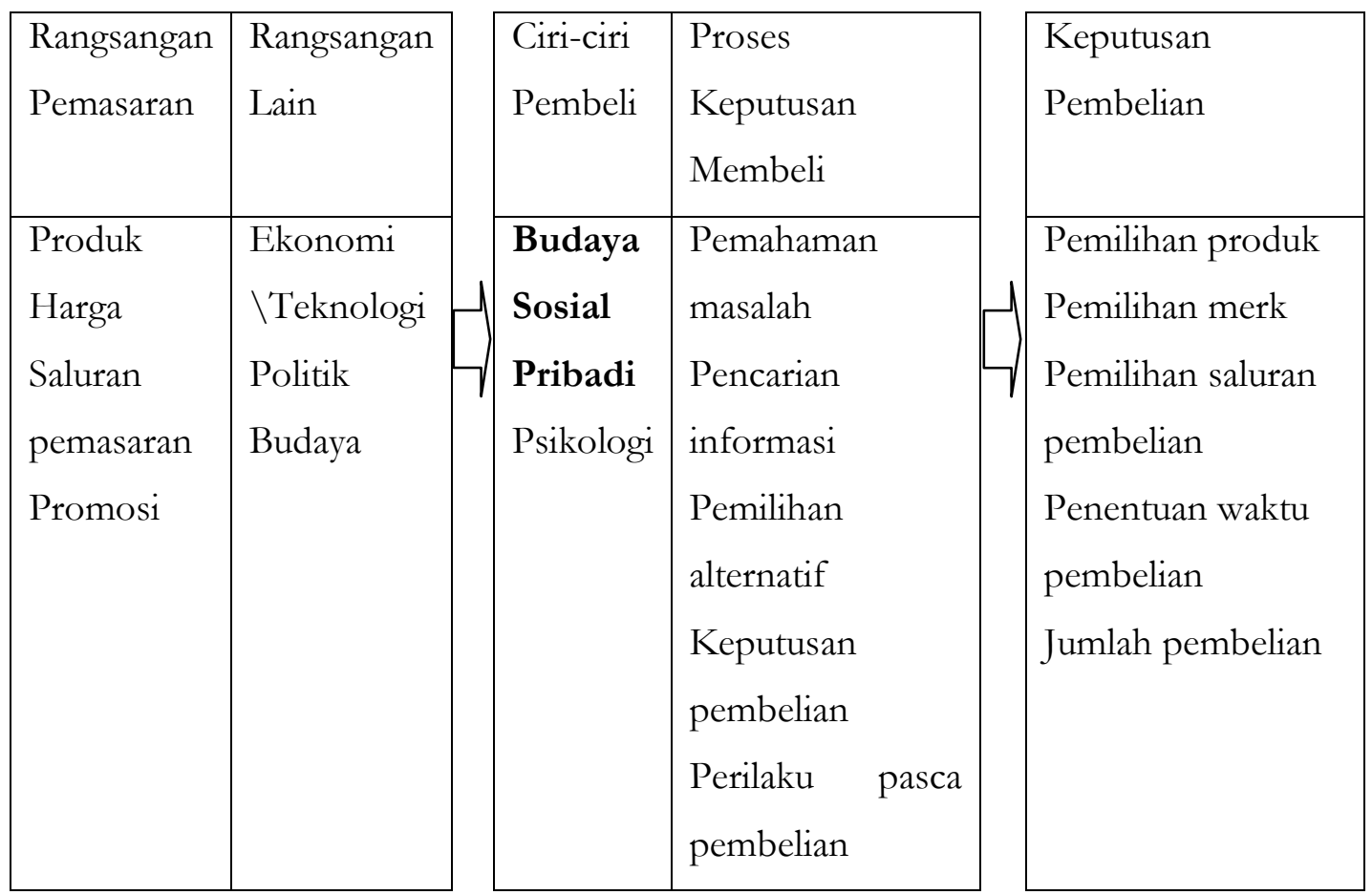

Arah Kajian Perilaku Konsumen

\section{ASPEK INTERNAL}

1. Kognisi

Pengtahuan dan keterlibatan produk

Proses pengelolaan informasi

Persepsi

Pembelajaran

Motivasi dan kebutuhan

2. Afeksi

Sikap

Kepribadian \& psikologis

Komunikasi
TINDAKAN

1. Pengenalan kebutuhan

2. Sumber informasi

3. Evaluasi \& alternatif produk

4. Seleksi \& tindakan pembelian produk

5. Pasca konsumsi produk

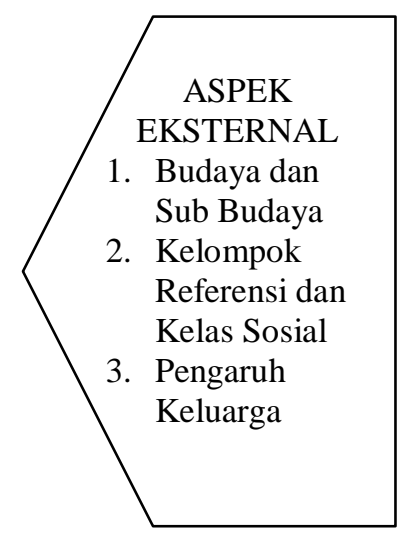

${ }^{37}$ Rini D PENGEMBANGAN $u$ Kon umen Malang: EVALUASI 15.

${ }^{38}$ Philip Kotler dan Keller, Kevin Lane, Manaj pren pemasaran Edisi 12 jilid 2. Ter. Benyamin Molan (Jakarta: Indeks, 2008), 214. 
Sosiologi ekonomi adalah studi sosiologis yang bertujuan untuk menganalisis hubungan antara ekonomi dan fenomena sosial. Asumsi yang dibangun sosiologi ekonomi dalam melihat fenomena ekonomi adalah tindakan ekonomi dilihat sebagai suatu bentuk tindakan sosial, tindakan ekonomi disituasikan secara sosial, dan institusi ekonomi merupakan konstruksi sosial. ${ }^{39}$

Sosiologi dan ekonomi mengalami disparitas field of study sejak ekonom klasik dan neoklasik mengembangkan teori-teori ekonomi tanpa institutional framework. Kontribusi teori kontemporer dalam sosiologi ekonomi adalah analisis ekonomi dengan pendekatan social embeddedness. Weber yang sosiolog, tidak pernah menyebutkan social embeddednes dalam teori sosiologi ekonomi-nya, namun beberapa sosiolog menyebut teori Weber sebagai 'The Hidden Theory of Embeddedness'. ${ }^{40}$

Pembahasan tentang hubungan masyarakat dan ekonomi dalam masyarakat primitif dimuat dalam buku Trade and Market in The Early Empires (1957) yang diedit bersama Arensberg dan Pearson. Perkembangan sosiologi ekonomi tentang social embeddedness dilakukan oleh Karl Polanyi pada 1950. Namun, Polanyi lebih banyak mengkaji aspek political economy dari embeddedness ketimbang social embeddedness itu sendiri. ${ }^{41}$

Social embeddedness dalam 'The New Economic Sociology' merupakan pendekatan sosiologi ekonomi yang melihat tindakan aktor ekonomi dalam kerangka struktur sosial. Namun, Granovetter lebih banyak menganalisis structure of social relation atau network terhadap fenomena ekonomi. Dalam teori social embeddedness, Granovetter berargumen bahwa aktor ekonomi harus dihindari dari proses atomisasi karena membuat aktor keluar dari konteks sosial. Hal ini untuk mencegah konsepsi 'undersocialized'. Tidak pula aktor ditempatkan dalam ruang-ruang determinasi kultural

\footnotetext{
${ }^{39}$ Damsar, Pengantar Sosiologi Ekonomi, 11-14.

40 Mark Skousen, Sang Maestro "Teori-Teori Ekonomi Modern": Sejarah Pemikiran Ekonomi. Edisi Pertama, ter. Tri Wibowo Budi Santoso (Jakarta: Prenada, 2012), 327.

${ }^{41}$ Damsar, Pengantar Sosiologi Ekonomi , 26.
} 
yang mengakibatkan 'oversocialized'. Namun, aktor ditempatkan pada struktur relasi sosial dalam sebuah sistem yang sedang berjalan. ${ }^{42}$

Sosiologi ekonomi dan ekonomi Islam dapat dibingkai oleh teori keterlekatan. Untuk memahami perilaku ekonomi diperlukan konsep keterlekatan, yaitu tindakan ekonomi yang disituasikan secara sosial dan melekat dalam jaringan sosial personal yang sedang berlangsung diantara para aktor. Pengaruh agama, budaya dan struktur sosial terhadap tindakan ekonomi telah lama menjadi polemik mazhab oversocialized dan undersocialized. Oversocialized adalah tindakan ekonomi kultural yang dituntun oleh norma dan nilai, sedangkan undersocialized merupakan tindakan ekonomi yang rasional yang berorientasi pada pencapaian keuntungan individu semata. $^{43}$

Teori struktural fungsional dan teori struktural konflik sama-sama berusaha menjelaskan struktur masyarakat. Perbedaannya, struktural fungsional menekankan pada fungsi dari elemen-emen pembentuk struktur, sedangkan struktural konflik menakankan pada perbedaan elemen-elemen pembentuk struktur. Dalam membahas perilaku konsumen sebuah struktur masyarakat, teori struktural fungsional lebih menemukan relevansinya. ${ }^{44}$

Ada 4 asumsi dasar yang dimiliki oleh teori struktural fungsional. Pertama, setiap masyarakat terdiri dari berbagai elemen yang terstruktur secara relatif mantap dan stabil. Kedua, elemen-elemen terstruktur tersebut terintegrasi dengan baik. Ketiga, setiap elemen dalam struktur memiliki fungsi yaitu memberikan sumbangan pada bertahannya struktur itu sebagai suatu sistem. ${ }^{45}$

Apabila teori struktural berusaha menjelaskan struktur masyarakat, maka teori interaksionisme simbolis memahami realitas sebagai suatu interaksi yang dipenuhi berbagai simbol. ${ }^{46}$ Kenyataan merupakan interaksi interpersonal yang menggunakan

42 M. Granovetter, "Problem of Explanation in Economic Sociology", dalam Network and organizations: Structure from and Action, ed.N. Nohria dan R Eccles (Boston: Harvard Businnes School Press, 1992).

${ }^{43}$ M. Granovetter, "Problem of Explanation in Economic Sociology, 132.

${ }^{44}$ George Ritzer \& Douglas J. Goodman Teori Sosiologi Modern, ter. Imam Muttaqien (Jakarta: Pranada Media, 2005), 273-283.

${ }^{45}$ Damsar, Pengantar Sosiologi Ekonomi , 55-57.

46Ibid., 60-62. 
simbol-simbol. Interaksionisme simbolis melakukan proses interpretatif, dimana individu secara aktif mengkonstruksikan tindakan-tindakannya dan proses interaksi dimana individu menyesuaikan diri dengan mengambil peran dan komunikasi simbol. 47

Interaksionisme simbolis lahir dari tradisi filsafat pragmatisme Amerika, yang mempercayai pada kekuatan keagenan individu dalam menghadapi struktur sosial. Tidak seperti kaum rasionalis filsafat Eropa, mereka melihat realitas itu dimanis, individu adalah knower aktif, makna (meanings) ${ }^{48}$ terkait dengan perspektif-perspektif dan tindakan sosial, serta pengetahuan adalah daya instrumental yang memungkinkan orang memecahkan masalah dan menata ulang dunia. ${ }^{49}$

Menurut Turner ada empat asumsi dari teori interaksionisme simbolis, yaitu : Manusia adalah makhluk yang mampu menciptakan dan menggunakan simbol, Manusia menggunakan simbol untuk saling berkomunikasi, Manusia berkomunikasi melalui pengambilan peran, serta asumsi bahwa Masyarakat terbentuk, bertahan dan berubah berdasarkan kemampuan manusia untuk berpikir, mendefiniskan, melakukan refleksi diri dan melakukan evaluasi. ${ }^{50}$

Model ekonomi syariah dibangun atas dasar filosofi religiusitas, dan institusi keadilan, serta instrumen kemaslahatan (Q.S. at-Takaatsur:1-2, al-Munaafiquun:9, anNuur:37, al-Hasyr:7, al-Baqarah:188, 273- 281, al-Maidah:38, 90-91, al-Muthaffifin:16). Filosofi religiusitas melahirkan basis ekonomi dengan atribut pelarangan riba/bunga. Institusi keadilan melahirkan basis teori profit and loss sharing (PLS) dengan atribut nisbah bagi hasil. Instrumen kemaslahatan melahirkan kebijakan pelembagaan zakat, pelarangan israf, dan pembiayaan (bisnis) halal, yang semuanya itu dituntun oleh nilai falah (bukan utilitarianisme dan rasionalisme). Ketiga dasar di atas, yakni filosofi religiusitas, institusi keadilan, dan instrumen kemaslahatan merupakan aspek dasar yang membedakan dengan mainstream ekonomi konvensional. ${ }^{51}$

${ }^{47}$ P.J. Johnson, Teori Sosiologi Klasik dan Modern. Jilid 1(Jakarta: Gramedia, 1981),37.

${ }^{48}$ H.S. Thayer, Meaning and Action. (Cambridge: Hackett Publishing Company, 1981)

${ }^{49}$ Dmitri Shalin, "Pragmatism and social Interactionisme", dalam American Sociologist Review (1986), 9-29.

${ }^{50}$ Damsar, Pengantar Sosiologi Ekonomi, 60-63.

51 Muhlis, "Perilaku Menabung di Perbankan Syari'ah Jawa Tengah" (Desertasi-Universitas Diponegoro, Semarang, 2011), 123-145. 
Konsumen muslim setelah memahami dan meyakini terhadap posisi bunga adalah dikategorikan riba, dan riba adalah dilarang agama, maka ia akan berusaha menjauhi segala kegiatan (ekonomi) bisnis yang berbasis riba/bunga. Pandangan ini akan keyakinan mutlaknya. Teori pilihan rasional Weber menggambarkan perilaku rasional manusia tidak bisa dilepaskan dari keyakinan akan nilai-nilai absolut tertentu, seperti nilai keagamaan (religiusitas), etika dan estetika atau nilai lainnya yang diyakini. 52

Preferensi konsumen menurut konsep syariah bukan berdasarkan pada semangat nilai rasionalisme dan utilitarianisme, tetapi berdasarkan nilai "falah" dalam teori Weber disebut nilai absolutisme agama. ${ }^{54}$

Diskursus keagamaan kontemporer menjelaskan, bahwa agama ternyata bukan lagi dipahami semata-mata terkait dengan persoalan ketuhanan atau keimanan semata. ${ }^{55}$ Keberagamaan (religiusitas) termanivestasi dalam kehidupan manusia. Religiusitas mencakup keadaan yang terdapat dalam diri seseorang yang mendorongnya berpikir, bersikap, bertingkah laku, dan bertindak sesuai dengan ajaran agamanya. Glock dan Stark menganalisis religiusitas ke dalam lima dimensi, yaitu dimensi keyakinan, praktik, pengalaman, pengetahuan, dan konsekuensi: ${ }^{56}$

Dengan demikian, religiusitas dapat digambarkan sebagai wujud konsistensi antara kepercayaan terhadap agama sebagai unsur kognitif, perasaan agama sebagai unsur afektif dan perilaku agama sebagai unsur psikomotorik. ${ }^{57}$ Religiusitas merupakan integrasi secara kompleks antara pengetahuan agama, perasaan serta tindakan keagamaan dalam diri seseorang pada semua aspek kehidupan.

Agama dan ideologi tertentu yang dianut sebagai pandangan kuat adalah memuat berbagai bentuk ajaran positif dalam mendorong manusia untuk melakukan sebuah tindakan. Ajaran-ajaran agama yang menjadi wacana keseharian manusia 1958).

${ }^{52}$ Max Weber, , The Protestant Ethics and The Spirit of Capitalism, New York: HarperCollins,

${ }^{53}$ M. Umer Chapra, Islam and the Economics Challenge, 211.

${ }^{54}$ Max Weber, General Economic History ter. H.H Gerth (New York: Free Press, 1961).

55 Amin Abdullah, Dinamika Islam Kultural. (Bandung : Mizan, 2000).

${ }^{56}$ C.Y. Glock, and R. Stark, American Piety: The Nature of Religious Commitment, 328.

${ }^{57}$ Jalaludin Rahmat, Islam Aletrnatif (Bandung, Mizan, 1986), 92. 
secara sadar maupun di bawah sadar menjadi dorongan teologis untuk melakukan berbagai aktivitas, termasuk kegiatan ekonomi.

Glock dan Stark menganalisis religiusitas ke dalam lima dimensi, yaitu dimensi keyakinan, praktik, pengalaman, pengetahuan, dan pengamalan:

Pertama, dimensi keyakinan berkenaan dengan seberapa tingkat keyakinan seseorang terhadap kebenaran ajaran agamanya, terutama terhadap ajaran-ajaran yang fundamental atau bersifat dogmatis. Dalam Islam, isi dari dimensi keyakinan adalah menyangkut keyakinan tentang adanya Allah, Malaikat, Rasul/Nabi, kitab Allah, surga, neraka, qadha dan qodar. ${ }^{58}$

Kedua, dimensi praktik berkenaan dengan seberapa tingkat kepatuhan seseorang dalam mengerjakan kegiatan-kegiatan ritual sebagaimana diperintahkan atau dianjurkan oleh agama yang dianutnya. Dalam Islam, isi dimensi ritualistik/praktik meliputi kegiatan-kegiatan seperti pelaksanaan shalat, puasa, haji (bila berkemampuan), pembacaan Al Qur'an, pemanjatan doa, dan lain sebagainya. ${ }^{59}$

Ketiga, Dimensi pengalaman berkenaan dengan seberapa tingkat seseorang dalam merasakan dan mengalami perasaan-perasaan dan pengalaman religius. Dalam Islam, isi dimensi pengalaman meliputi perasaan dekat dengan Allah, dicintai Allah, doa-doa sering dikabulkan, perasaan tenteram dan bahagia karena menuhankan Allah $^{60}$, dan diselamatkan dari musibah, menerima pendapatan yang tidak terpikirkan sebelumnya, seperti hibah, hadiah, dan warisan.

Keempat, dimensi pengetahuan berkenaan dengan seberapa tingkat pengetahuan dan pemahaman seseorang terhadap ajaran agamanya, terutama mengenai ajaran pokok sebagaimana termuat dalam kitab sucinya. Dalam Islam, isi dimensi intelektual/ pengetahuan meliputi pengetahuan tentang isi Al-Quran, pokokpokok ajaran yang harus diimani dan dilaksanakan, hukum Islam ${ }^{61}$, dan pemahaman terhadap kaidah-kaidah keilmuan ekonomi Islam/perbankan syariah.

58 Jamaluddin Ancok dan F. Nashori, Psikologi Islami, Solusi atas Problem-problem Psikologi (Yogyakarta, Pustaka Pelajar, 2002), 18.

${ }^{59}$ Jamaluddin, Psikologi Islami, Solusi atas Problem-problem Psikologi, 32.

${ }^{60}$ Ibid., 93.

${ }^{61}$ Ibid., 95 
Kelima, dimensi pengamalan berkenaan dengan seberapa tingkat seseorang dalam berperilaku yang dimotivasi oleh ajaran agamanya. Perilaku yang dimaksud adalah perilaku duniawi, yakni bagaimana individu berhubungan dengan dunianya. Dalam Islam, isi dimensi pengamalan/konsekuensi meliputi perilaku suka menolong, berderma, menegakkan kebenaran dan keadilan, berlaku jujur, menjaga amanat, menjaga lingkungan, tidak mencuri, tidak berjudi, tidak menipu, berjuang untuk kesuksesan hidup menurut ukuran Islam ${ }^{62}$, dan mematuhi serta menjalankan normanorma Islam dalam berbudaya, bermasyarakat, berpolitik, dan berekonomi (transaksi bisnis/perbankan) secara non-riba.

Perilaku yang bersifat teologis maupun sosial mencerminkan pengejawantahan tata norma dogmatif pada kehidupan kemasyarakatan. ${ }^{63}$ religiusitas dapat didefinisikan sebagai tindakan mengekpresikan ajaran agama melalui perilaku ritual ibadah mahd $\} a h$ serta ibadah ghairu mahd $\} a h$, yakni sosial kemasyarakatan. ${ }^{64}$ Wujud kehidupan sosial kemasyarakatan dapat dijalankan pada sektor budaya, politik, hukum, dan ekonomi.

Perilaku konsumen muslim dalam bebearap studi yang dilakukan, mempunyai karakter yang berbeda-beda. Terdapat berbagai penelitian yang telah dilakukan untuk mengetahui perilaku konsumen dan alasan pemilihan bank syari'ah. Keberagamaan bukan sebagai faktor utama pemilihan bank syari'ah dilakukan oleh peneliti di luar Indonesia antara lain oleh : Erol dan El-Bdour (1989), Haron et al. (1994), Gerrard dan Cunningham, Jalaluddin dan Metwally (1999). Sedang peneliti Indonesia antara lain : Anny Ratnawati, et. al. (2000), Jazim Hamidi, et. al. (2000).

Pada tahun 1989 , Erol dan El-Bdour sebagai peneliti pertama perbankan syariah melakukan penelitian terhadap 434 nasabah bank Islam dan konvensional di Jordania, dengan menggunakan teknik statistik univariate dan multivariate serta analisis faktor. Hasil yang diperoleh menyebutkan, bahwa agama bukan motivasi utama bagi nasabah yang menggunakan bank Islam. Dua tahun kemudian yaitu tahun

${ }^{62}$ Ibid., 96

${ }^{63}$ M. M Poloma \& B. F Pendleton,. Religious domains and general well-being. Social Indicators Research, 22(1990),, 255-276.

${ }^{64}$ Amin Abdullah, Dinamika Islam Kultural, 46. 
1990 Erol dan El-Bdour mengulangi penelitian serupa dengan melibatkan pakar lain, yakni Kaynak. Hasilnya tetap saja menunjukkan, bahwa tidak ada pengaruh agama terhadap kriteria pemilihan bank. ${ }^{65}$

Haron pada tahun 1994 melakukan penelitian terhadap 301 muslim dan non muslim di Malaysia. Kesimpulan penelitian yang menerapkan teknik statistik univariate dan multivariate serta analisis faktor ternyata menunjukkan, bahwa motivasi agama bukan motivasi utama bagi muslim dalam memilih bank Islam. Gerrard dan Cunningham tahun 1997 melakukan penelitian di Singapura terhadap 190 responden. ${ }^{66}$ Dengan teknik statistik univariate dan multivariate serta analisis factor, ternyata sikap komunitas muslim berbeda dengan non muslim mengenai motivasi religius dan profitabilitas. Jalaluddin dan Metwally di tahun 1999 meneliti 385 perusahaan kecil di Sydney, Australia. Hasil penelitian dengan analisis logit dan probit menunjukkan, bahwa agama bukanlah satu-satunya faktor yang memotivasi perusahaan kecil di Australia untuk menggunakan metode pembiayaan bagi hasil. ${ }^{67}$

Anny Ratnawati, pada tahun 2000 melakukan penelitian tentang potensi, preferensi \& perilaku masyarakat di wilayah Jawa Barat, dengan variabel dependen keputusan memilih bank syariah, dan variabel independen antara lain terdiri dari informasi tentang bank syariah, dan pertimbangan syariah. Hasil penelitian menunjukkan, bahwa faktor pertimbangan keagamaan (yaitu masalah halal/haram bunga) bukanlah menjadi faktor penting dalam mempengaruhi kecenderungan menggunakan jasa bank syariah. ${ }^{68}$

Penelitian serupa dilakukan oleh Jazim Hamidi bersama tim pada tahun 2000. Responden yang dipilih adalah masyarakat santri Jawa Timur dengan cakupan 4 (empat) kategori, yakni: ulama, siswa santri, alumni santri, dan masyarakat sekitar pesantren. Setelah dilakukan analisis data dengan statistik deskriptif akhirnya

${ }^{65}$ C. Erol and R. El-Bdour (1989). "Attitudes, Behaviour and Patronage Factors of Bank Customers Towards" International Journal of Bank Marketing 15(4)

${ }^{66}$ P. Gerrard and J. Cunningham, "Islamic Banking: A Study in Singapore." International Journal of Bank Marketing 15(6) (1997): 204- 216.

${ }^{67}$ M. Metwally, "The Impact of Demographic Factors on Consumers' Selection of a Particular Bank within a Dual Banking System: A Case Study.” Journal of International Marketing and Marketing Research 27(1) M (2002), 35-44.

${ }_{68}$ Anny Ratnawati, "Potensi Preferensi \& Perilaku Masyarakat di Wilayah Jawa Barat" (Bogor: IPB dan BI, 2002), 23. 
menghasilkan kesimpulan antara lain, bahwa faktor pertimbangan keagamaan (yaitu masalah halal/haram bunga) bukanlah menjadi faktor penting dalam mempengaruhi kecenderungan menggunakan jasa bank syariah. ${ }^{69}$

Jika berbagai hasil penelitian di atas melihat agama bukanlah merupakan motivasi utama dalam memanfaatkan perbankan syariah, maka penelitian-penelitian di bawah ini justeru berbalikan. Agama merupakan faktor penting ditunjukkan oleh peneliti di luar Indonesia oleh: Omer (1992), Hegazy (1995), Metwally (1996), Metawa dan Almossawi (1998), Naser, et al. (1999), Al-Sultan (1999), Ahmad dan Haron (2002), Okumus (2005), Kadom dan Alzafiri (2008), Mehboob ul Hassan( 2007.). sedang penelitian dalam negeri dilakukan oleh : Fatmah (2005) dan Nur Widiastuti (2003), dan Muhlis (2010).

Tahun 1992, Omer melakukan penelitian terhadap 300 Muslim yang tinggal di Inggris. Kesimpulannya, bahwa alasan-alasan agama merupakan motivasi pokok bagi Muslim di Inggris untuk memilih lembaga keuangan Islam. ${ }^{70}$ Penelitian Hegazy tahun 1995 terhadap 400 nasabah dari Faisal Islamic Bank Mesir dan Bank of Commerce and Development menunjukkan, bahwa pemilihan bank Islam bagi kebanyakan nasabah muslim karena dilandasi oleh kepatuhan terhadap hukum Islam. ${ }^{71}$ Pada tahun 1996 Metwally juga melakukan penelitian terhadap 385 nasabah di Kuwait, Arab Saudi dan Mesir. Hasil penelitian menunjukkan, bahwa faktor paling penting di dalam menentukan sikap muslim memilih bank Islam adalah agama. ${ }^{72}$

Metawa dan Almossawi di tahun 1998 melakukan penelitian dengan instrumen kuesioner terhadap 300 nasabah bank Islam di Bahrain. Penelitian ini menerapkan analisis data uji statistik non parametrik. Hasil penelitiannya menyatakan, bahwa faktor terpenting terhadap motivasi penggunaan jasa bank Islam adalah

${ }^{69}$ Jazim Hamidi, "Persepsi dan Sikap Masyarakat Santri Jawa Timur terhadap Bank Syariah", (Malang: BI dan Universitas Brawijaya Malang, 2000), 45.

${ }^{70}$ H.S.H.Omer, "The implications of Islamic beliefs and practice on the Islamic financial institutions in the UK: case study of Albaraka International Bank UK"(Desertasi --Loughborough University, Loughborough ,1992), 112.

${ }^{71}$ I. Hegazy, "An Empirical Comparative Study between Islamic and Commercial Banks' Selection Criteria in Egypt." International Journal of Commerce and Management 5(3) (1995): 46-61.

72 M. Metwally, "The Impact of Demographic Factors on Consumers' Selection of a Particular Bank within a Dual Banking System: A Case Study." Journal of International Marketing and Marketing Research 27(1) (2002): 35-44. 
landasan agama (religiusitas) yang ditunjukkan dengan tidak menggunakan instrumen bunga sebagai landasan operasional perbankan. ${ }^{73}$

Di Kuwait, Al-Sultan melakukan serangkaian penelitian terhadap 385 responden. Penelitiannya melibatkan variabel-variabel demografi, sosial budaya, layanan bank Islam dan alasan-alasan preferensi. Akhirnya diperoleh kesimpulan bahwa kepatuhan terhadap agama Islam merupakan motivasi utama untuk bertransaksi dengan bank Islam. ${ }^{74}$

Di tahun 2002 Ahmad dan Haron melakukan penelitian terhadap 45 direktur keuangan, manajer keuangan dan manajer umum di Malaysia dengan instrumen kuesioner. Varibel penelitian terdiri dari faktor demografi, jasa perbankan Islam dan konvensional, pertanyaan pengetahuan dan faktor patronase tertentu oleh responden. Kesimpulan penelitian menunjukkan kebanyakan responden memilih faktor ekonomi dan agama secara bersama sama merupakan faktor penting dalam memilih jasa bank. Meskipun sebagian besar responden adalah non muslim, tetapi sebagian besar mengetahui tentang bank Islam. ${ }^{75}$

Pada tahun 2003 Nur Widiastuti melakukan penelitian tentang issu pengaruh religiusitas (juga pendapatan, dan tanggungan keluarga) terhadap jumlah tabungan, dengan variabel dependen jumlah tabungan dan salah satu variabel independennya adalah religiusitas. Menurutnya, Islam tidak hanya mengenal aktifitas vertikal tetapi juga aktifitas horisontal yang secara ekonomi berkait dengan muamalah. ${ }^{76}$

Okumus tahun 2005 melakukan penelitian di Turki dengan instrumen penggalian data kuesioner terhadap 161 nasabah bank Islam. Hasil penelitian menyatakan bahwa sebagian responden setuju agama merupakan alasan utama bagi penggunaan produk-produk bank Islam. Motivasi sekunder nasabah memilih bank Islam karena prinsip operasinya yang bebas bunga. ${ }^{77}$

\footnotetext{
${ }^{73} \mathrm{~S}$. Metawa, and M. Almossawi, "Banking Behaviour of Islamic Bank Customers: Perspectives and Implications." International Journal of Bank Marketing 16(7) (1998): 299-315.

74 W. al-Sultan, "Financial Characteristics of Interest-Free Banks and Conventional Bank Accounting and finance”(Desertasi-- The University of Wollongong, Wollongong, 1999), 221-234.

${ }^{75} \mathrm{~N}$. Ahmad and S. Haron, "Perceptions of Malaysian Corporate Customers Towards Islamic Banking Products and Services.”International Journal of Islamic Financial Services 3(4) (2002).

${ }^{76}$ Nur Widiastuti, "Pengaruh Relijiusitas, Pendapatan 27.

${ }^{77} \mathrm{H}$. Okumus, "Interest-Free Banking in Turkey: A Study of Customer Satisfactin and Bank Selection Criteria." Journal of Economic Cooperation 26(4) (2005):: 51-86.
} 
Tahun 2005, Fatmah melakukan penelitian disertasi tentang pengaruh persepsi religiusitas layanan dan lnovasi produk terhadap kepercayaan dan komitmen serta loyalitas nasabah bank umum Syariah di Jawa Timur. Kesimpulan Penelitian antara lain sebagai berikut: Terdapat pengaruh positif dan signifikan antara persepsi religiusitas dengan kepercaaan, komitmen dan loyalitas nasabah bank syariah. ${ }^{78}$

Tahun 2007 di Pakistan, Mehboob ul Hassan melakukan penelitian tentang People's Perceptions towards the Islamic Banking: A Fieldwork Study on Bank Account Holders' Behaviour in Pakistan. Kesimpulan yang diperoleh dari penelitian ini antara lain adalah kekuatan visi keislaman (religiusitas) mendorong persepsi masyarakat, bahwa tingkat bunga tabungan tidak menjadi persoalan bagi sebagian besar umat muslim. Besar kecilnya return dianggap tidak penting dibandingkan dengan return investasi yang sah atau dibolehkan agama. ${ }^{79}$

Di tahun 2008, Kadom dan Alzafiri meneliti nasabah Kuwait Finance House (KFH), Dubai Islamic Bank (DIB), Qatar Islamic Bank (QIB), Bahrain Islamic Bank (BIB) dengan analisis multivariat. Kesimpulan penelitian tersebut, bahwa penabung memilih bank Islam karena agama. ${ }^{80}$

Tahun 2010, Mukhlis melakukan penelitian disertasi terhadap 400 nasabah Bank mu'amalat Bank Syari'ah Mandiri dan Bank Mega Syari'ah di Jawa Tengah. Kesimpulan Penelitian antara lain: Religisusitas berpengaruh signifikan terhadap nasabah yang hanya mempunyai rekening di bank syari'ah, berpengaruh positif tetapi tidak signifikan bagi nasabah non muslim dan nasabah muslim yang mempunyai rekening di bank syari'ah dan bank konvensional. ${ }^{81}$

\section{Kesimpulan}

\footnotetext{
${ }^{78}$ Fatmah, "Pengaruh Persepsi Religiusitas, Kualitas Layanan, 26.

${ }^{79}$ Mehboob ul Hassan, "People's Perceptions towards the Islamic Banking: A Fieldwork Study on Bank Account Holders' Behaviour in Pakistan”, 467-850.

${ }^{80} \mathrm{Ahmad}$, "Perceptions of Malaysian Corporate Customers Towards Islamic Banking Products and Services.", 34).

${ }^{81}$ Muhlis, "Perilaku Menabung di Perbankan Syari'ah Jawa Tengah" (Desertasi-Universitas Diponegoro, Semarang, 2011), 238-241.
} 
Perilaku konsumen di perbankan syari'ah dikaji dalam perspektif Hukum Islam, Ilmu Ekonomi, Sosiologi, Psikologi dan Antropologi merupakan bentuk kolaborasi yang kemudian menjadi interdisipliner.

Keberaragamaan dapat mempengaruhi nasabah dalam pemilihan bank syari'ah. Keberagamaan bukan sebagai faktor utama pemilihan bank syari'ah dilakukan oleh peneliti di luar Indonesia antara lain oleh : Erol dan El-Bdour, Haron et al.), Gerrard dan Cunningham, Jalaluddin dan Metwally. Sedang peneliti Indonesia antara lain : Anny Ratnawati, et. al. Jazim Hamidi, et. al.

Jika berbagai hasil penelitian sebelumnya melihat agama bukanlah merupakan motivasi utama dalam memanfaatkan perbankan syariah, maka penelitian-penelitian di bawah ini justeru sebaliknya. Agama merupakan faktor penting ditunjukkan oleh peneliti di luar Indonesia oleh: Omer, Hegazy Metwally Metawa dan Almossawi, Naser, et al., Al-Sultan, Ahmad dan Haron, Okumus , Kadom dan Alzafiri, Mehboob ul Hassan .

\section{DAFTAR PUSTAKA}

Abdullah, Amin. Dinamika Islam Kultural. Bandung : Mizan, 2000.

Abidin , Zainal. "Kyai dan Bisnis di Pamekasan Madura Studi Tentang Dinamika, Strategi dan Nilai Spiritualitas Bisnis".Desertasi-- UIN Sunan Ampel, Surabaya, 2014.

Ahmad, N. and S. Haron , "Perceptions of Malaysian Corporate Customers Towards Islamic Banking Products and Services."International Journal of Islamic Financial Services 2002.

Ancok, Jamaluddin dan F. Nashori. Psikologi Islami, Solusi atas Problem-problem Psikologi. Yogyakarta, Pustaka Pelajar, 2002.

Assael H. Consumer Behavior and marketing Action. Boston: Wadsworth ,1992.

Chapra, M. Umer. Islam and the Economics Challenge. Leicester, UK : The Islamic Foundation, 1992.

Chotimah, Chusnul. "Strategi Public Relations Pesantren Sidogiri dalam membangun citra Lembaga Pendidikan Islam”, Islamica, Vol VII, No. 1 . September 2012.

Damsar dan Indrayani. Pengantar Sosiologi Ekonomi. Jakarta: Kencana, 2013. 
Dilthey, Wilhelm. Pattern and Meaning in History. Newyork: Harper \& Row, 1962.

Erol , C. and R. El-Bdour . "Attitudes, Behaviour and Patronage Factors of Bank Customers Towards" International Journal of Bank Marketing 15, 1989.

Fatmah. "Pengaruh Persepsi Religiusitas, Kualitas Layanan, dan Inovasi Produk terhadap Kepercayaan dan Komitmen serta Loyalitas Nasabah Bank Umum Syariah di Jawa Timur". Desertasi-- Unair Surabaya Surabaya, 2005.

Gerrard P. and J. Cunningham, "Islamic Banking: A Study in Singapore." International Journal of Bank. Marketing 1997.

Glock, C.Y. and R. Stark. American Piety : The Nature of Religious Commitment. USA: University of Chicago Press, 1968.

Granovetter, M. "Problem of Explanation in Economic Sociology", dalam Network and organizations: Structure from and Action, ed. N. Nohria et al. Boston: Harvard Businnes School Press, 1992.

Hamidi, Jazim. "Persepsi dan Sikap Masyarakat Santri Jawa Timur terhadap Bank Syariah”. Malang: BI dan Universitas Brawijaya Malang, 2000.

Hassan, Mehboob ul, "People's Perceptions towards the Islamic Banking: A Fieldwork Study on Bank Account Holders' Behaviour in Pakistan", School of Economics. Japan : Nagoya City University, 2007.

Hegazy, I. "An Empirical Comparative Study between Islamic and Commercial Banks' Selection Criteria in Egypt." International Journal of Commerce and Management 1995.

Johnson, P.J. Teori Sosiologi Klasik dan Modern Jilid 1. Jakarta: Gramedia, 1981.

Kaelan. Metode Penelitian Agama Kualitatif Interdisipliner. Yogyakarta: Paradigma, 2010.

Kane, Eileen. Dosin Your Own Research. London: Marion Boyars, 1985.

Kirk, Jerome \& Mare L. Miller. Releability and Validity in Quality Research, Vol I. Beverly Hills: Sage Publication, 1986.

Kotler, Philip dan Keller, Kevin Lane. Manajemen pemasaran Edisi 12 jilid 2. Ter. Benyamin Molan. Jakarta: PT. Indeks, 2007.

Metawa, S. and M. Almossawi, "Banking Behaviour of Islamic Bank Customers: Perspectives and Implications.” International Journal of Bank Marketing 1998. 
Metwally, M. "The Impact of Demographic Factors on Consumers' Selection of a Particular Bank within a Dual Banking System: A Case Study." Journal of International Marketing and Marketing Research 2002.

Muhlis. "Perilaku Menabung di Perbankan Syari'ah Jawa Tengah" (DesertasiUniversitas Diponegoro, Semarang, 2011.

Okumus, H. . "Interest-Free Banking in Turkey: A Study of Customer Satisfactin and Bank Selection Criteria." Journal of Economic Cooperation .2005.

Omer, H.S.H. "The implications of Islamic beliefs and practice on the Islamic financial institutions in the UK: case study of Albaraka International Bank UK”. Desertasi --Loughborough University, Loughborough ,1992.

Patton, Michael Quinn. Qualitative Evaluation Methodes. Beverly Hills: Sage Publication, 1980.

Poloma, M. M \& B. F Pendleton. Religious domains and general well-being. Social Indicators Research, 1990.

Rahmat, Jalaludin. Islam Aletrnatif. Bandung, Mizan, 1986.

Ratnawati, Anny. "Potensi Preferensi \& Perilaku Masyarakat di Wilayah Jawa Barat" . Bogor: IPB dan BI, 2002.

Ritzer, George \& Douglas J. Goodman. Teori Sosiologi Modern, ter. Imam Muttaqien. Jakarta: Pranada Media, 2005.

Schiffman, Leon G. dan Leslie Lazar Kanuk. Perilaku Konsumen ter. Zoelkifli Kasip. Jakarta:Indeks, 2008.

Shalin, Dmitri. "Pragmatism and social Interactionisme", dalam American Sociologist Review 1986.

Skousen, Mark. Sang Maestro "Teori-Teori Ekonomi Modern": Sejarah Pemikiran Ekonomi. Edisi Pertama, ter. Tri Wibowo Budi Santoso. Jakarta: Prenada, 2012.

Sugiyono. Memahami Penelitian Kualitatif .Bandung: Alfabeta, 2008.

Sultan (al) ,W. "Financial Characteristics of Interest-Free Banks and Conventional Bank Accounting and finance". Desertasi-- The University of Wollongong, Wollongong, 1999.

Thayer, H.S. Meaning and Action. Cambridge: Hackett Publishing Company, 1981. 
Uha, Ismail Nawawi. Isu-Isu Ekonomi Islam : Kompilasi Pemikiran dan Teori Menuju Praktik di Tengah Arus Ekonomi Global. Buku 1 Nalar Filsafat . Jakarta : Viv Press, 2013.

--Ekonomi Manajerial: teori dan Aplikasi Dalam Bisnis. Sidoarjo, Dwiputra Pustaka Jaya, 2014.

Vredenbregt, J. Metode dan Teknik Penelitian Masyarakat. Jakarta: Gramedia, 1981.

Weber, Max. The Protestant Ethics and The Spirit of Capitalism. New York: HarperCollins, 1958.

General Economic History ter. H.H Gerth. New York: Free Press, 1961.

Widiastuti, Nur. "Pengaruh Relijiusitas, Pendapatan, dan Tanggungan Keluarga terhadap Jumlah Tabungan", Jurnal Telaah Bisnis, Vol.4, Nomor 2. Desember 2003. 